\title{
A rare consequence of very common osteoporotic pubic rami fracture in a patient with myeloproliferative disease
}

\author{
Chathuri Liyanapthirana, Rosie Neal, Todor Iordanov, Aktham Nahhas
}

Geriatrics, Eastbourne District General Hospital, Eastbourne, East Sussex, UK

\section{Correspondence to} Dr Chathuri Liyanapthirana, chathuril@live.com

Accepted 23 June 2017

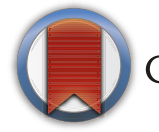

CrossMark

To cite: Liyanapthirana C, Neal R, lordanov T, et al. BMJ Case Rep Published Online First: [please include Day Month Year]. doi:10.1136/ bcr-2017-221079

\section{DESCRIPTION}

An 80-year-old female with janus kinase 2 positive myeloproliferative disease with stable blood parameters on aspirin and anagrelide admitted to the emergency department after a fall over the kerb complaining of pain limiting mobility. Initial assessment was stable without any external injuries noted. Pelvic X-ray demonstrated a stable pubic rami fracture (figure 1). Later on, her haemoglobin dropped $106 \mathrm{~g} / \mathrm{dL}$ to $67 \mathrm{~g} / \mathrm{dL}$ for no apparent cause. She was also noted to have an abdominal fullness and examination revealed a suprapubic mass. CT scan showed a well-defined hypointense collection measuring $85 \times 60 \times 105 \mathrm{~mm}$ extending superiorly from the symphysis pubis compressing bladder (figure 2-4). It was compatible with a late development of a haematoma. There was no contrast extravasation suggesting active bleeding. Her platelets and coagulation were normal. She was managed conservatively with blood transfusions but there was a place for angiography if she was to remain unstable.

Unlike with high-energy pelvic fractures seen in young males following poly trauma, it is not very common to have bleeding with low-energy osteoporotic fractures. ${ }^{1}$ This is an uncommon occurrence of a large palpable haematoma, ${ }^{12}$ secondary to fragility pubic rami fracture in the presence of a prothrombotic condition. This unusual delayed development of haematoma seen in her can be attributed to the following

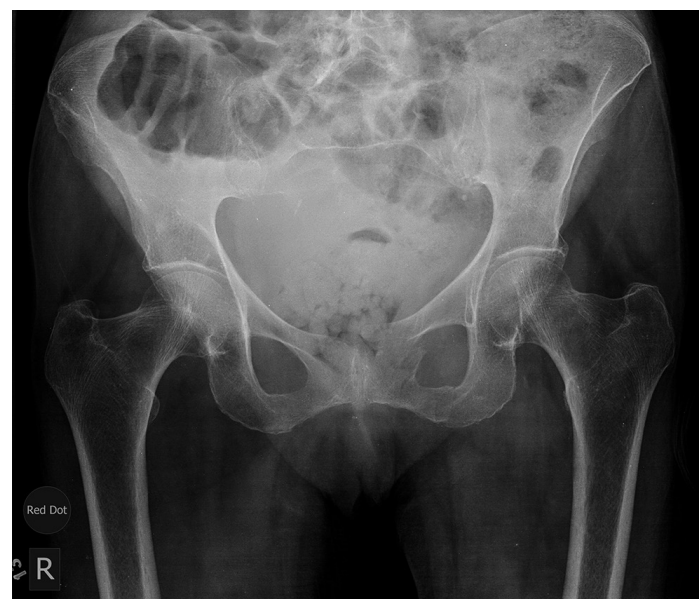

Figure 1 X-ray pelvis showing the fractures of superior and inferior pubic rami on the left.

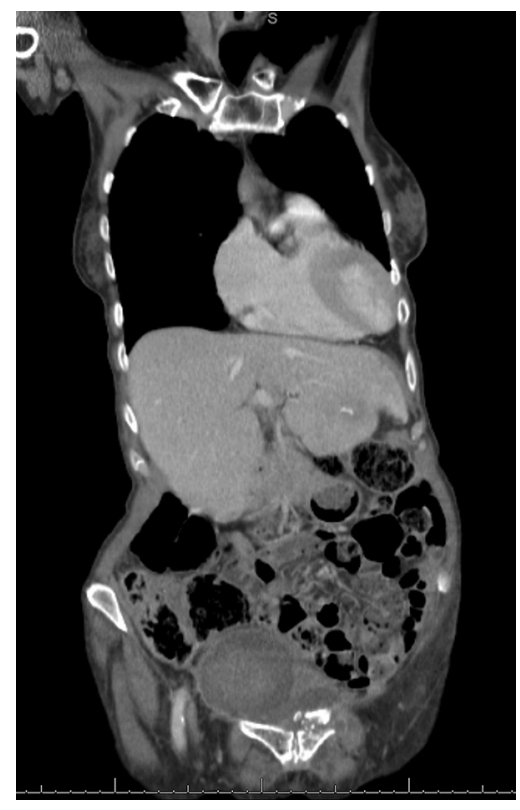

Figure 2 CT pelvis showing the well-defined hypointense collection seen in the superficial pelvis. Also note the fractures in the left rami.

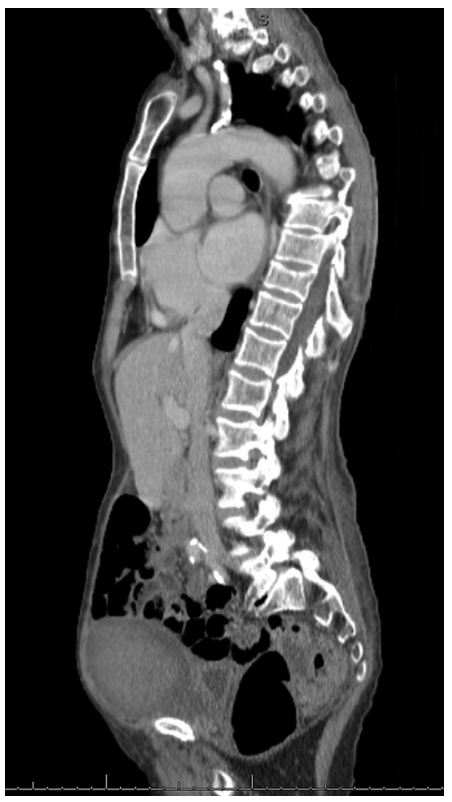

Figure 3 Parasagittal section of the CT showing the well-defined collection situated anterior to the bladder extending to superficial pelvis. 


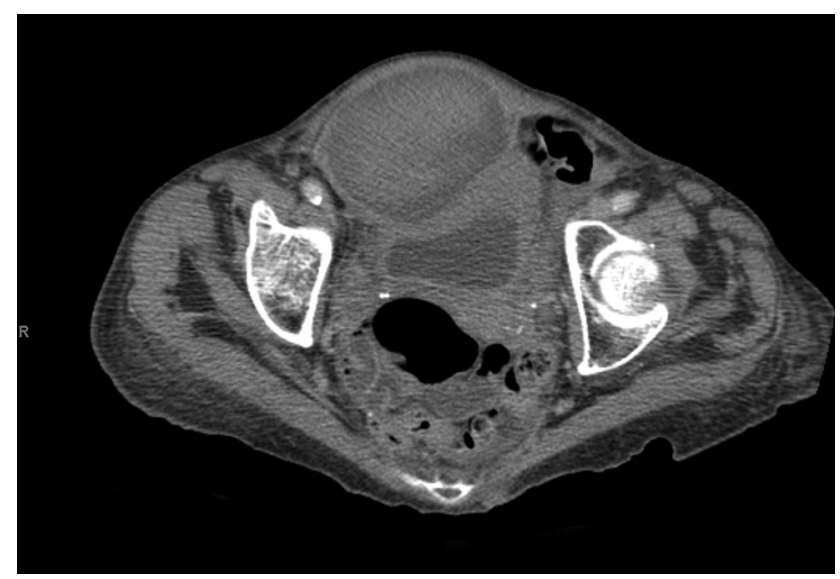

Figure 4 Cross-sectional image over pelvis showing the anteriorly situated hypointense collection (haematoma) compressing bladder posteriorly.

facts. She being on aspirin despite normal platelets, the prophylactic enoxheparin given to prevent deep vein thrombosis and the fact that geriatric patients have lost their ability to mount an effective tamponade effect due to loss of vasospasm and tissue elasticity.

\section{Learning points}

- Low-energy osteoporotic fractures despite being stable injuries, being managed conservatively pose a serious health hazard to elderly patients.

- Even in the presence of a prothrombotic conditions, it is better to be cautious when prescribing deep vein thrombosis prophylaxis for patients with pelvic fractures who are otherwise of low risk category (mobilising).

Acknowledgements To Nicholas Taylor, MIMI,MRCR(Hon) Honorary Teaching Fellow in Brighton and Sussex medical school for image set up.

Contributors $\mathrm{CL}$ was involved in managing the patient and writing up the case. RN was responsible for arranging investigations and getting the images. TL did the initial clerking and management of the patient. AN reviewed the case.

Competing interests None declared.

Patient consent Obtained.

Provenance and peer review Not commissioned; externally peer reviewed.

(C) BMJ Publishing Group Ltd (unless otherwise stated in the text of the article) 2017. All rights reserved. No commercial use is permitted unless otherwise expressly granted.

\section{REFERENCES}

1 Krappinger D, Kammerlander C, Hak DJ, et al. Low-energy osteoporotic pelvic fractures. Arch Orthop Trauma Surg 2010;130:1167-75.

2 Sandri A, Regis D, Bizzotto N. Delayed bleeding and pelvic haematoma after low-energy osteoporotic pubic rami fracture in a warfarin patient: an unusual cause of abdominal pain. Case Rep Emerg Med 2014;2014:1-4.

Copyright 2017 BMJ Publishing Group. All rights reserved. For permission to reuse any of this content visit

http://group.bmj.com/group/rights-licensing/permissions.

BMJ Case Report Fellows may re-use this article for personal use and teaching without any further permission.

Become a Fellow of BMJ Case Reports today and you can:

- Submit as many cases as you like

- Enjoy fast sympathetic peer review and rapid publication of accepted articles

- Access all the published articles

- Re-use any of the published material for personal use and teaching without further permission

For information on Institutional Fellowships contact consortiasales@bmjgroup.com

Visit casereports.bmj.com for more articles like this and to become a Fellow 